\title{
B. Steger, and A. McNevin (eds): Global ideologies and urban landscapes
}

\author{
Routledge, London, 2011, 134 p, ISBN 978-0-415-59863-7
}

\section{Richard Ronald}

Published online: 20 June 2012

(C) The Author(s) 2012. This article is published with open access at Springerlink.com

In essence this book is not a book. It is rather a special issue of the journal Globalizations from 2010 that has been reconfigured, without any content changes, into a Routledge hardback volume. The point is that, even by the standards of a typical edited text, the chapters in this book do not follow each other particularly fluidly nor fit together that coherently. The editors make a bold job of identifying the links in the introductory chapter, which originally of course was the editorial. The overarching concern is that urban landscapes are shaped by the interaction of ideology and space. More specifically, it is argued that cities are shaped by ideas that occur in 'scapes' through which we come to know our social environments. The editors explore this idea quite convincingly identifying the normative ways that urban spaces can and have been framed in order to facilitate 'truths', especially those that legitimate and facilitate some political projects while constraining others. Here, globalization and neoliberalization are implicated as critical forces and ideologies that have helped reshape urban scapes and defined how cities and public spaces have been developed in recent decades. By constraining the shape and meaning of space, and public spaces in particular, ideological diversity has been reined in allowing for only capital orientated contestations of what constitutes the social good.

This argument concerning the relationship between ideas and space in late capitalism provides the glue for the rest of the text, or at least a way of thinking how such an eclectic set of papers may fit together. The subsequent nine chapters focus on different theoretical ideas and empirical data with an eye to spatial and ideological conflicts, contradictions and continuities as they are played out across a variety of global contexts, from Sydney to Toronto, Berlin to Hong Kong, Las Vegas to Macau.

The second chapter is in my view the most influential one. Not only because it sets out a common language and theoretical frame from which to think about the rest of the volume, but also because it in itself constitutes an important work. The chapter 'After

\footnotetext{
R. Ronald $(\bowtie)$

Department of Geography, Planning and International Development Studies, The University of Amsterdam, Amsterdam, The Netherlands e-mail: R.Ronald@uva.nl

R. Ronald

Department of Housing and Interior Design, Kyung Hee University, Seoul, South Korea
} 
Neoliberalization' by Neil Brenner, Jamie Peck and Nik Theodore, sets out a post-Global Financial Crisis perspective on the very nature of neoliberalism: how it has developed and how it may continue to evolve in the post-crisis world. Of course, this article is likely to have been written in the year after the downfall of Lehman Brothers and in the first wake of the Credit Crunch and thus lacks the insight that subsequent crises in sovereign debt etc., have provided. Nonetheless, it condenses and provides a framework for understanding the story of neoliberalization up to the crisis, and also speculates on how public life, political debates, government and governance may emerge from the socioeconomic shock. The theoretical focus of this chapter contrasts with the rest of the volume which is made up of mostly empirical stories from different parts of the world, often in the form of rather unpredictable city comparisons. These papers, nonetheless, more meaningfully connect urban landscapes and ideologies, and their interactions, as set out at the start of the book.

Chapter three by James Goodman explores the contestation of public space in context of global summits and high profile international meetings such as the World Economic forum. The setting in this case is Sydney, Australia and Goodman explores how over the years that market globalist agendas have become normalized and have increasingly appropriated local public space. Moreover, he identifies how such events have been able to delegitimize protests against them. In chapter four Margaret Kohn examines a contrasting scenario in Toronto, Canada, where distillery districts have been renovated in order to rebrand the local area. The contradiction set up here is between the preservation of space for artisans and small scale production (as a kind of nostalgic or alternative community) as a means to market the area to middle class condominium buyers. Essentially Kohn is talking about the commodification of de-commodification and how it is played out in urban space. Within a similar theme, Chris Hudson in chapter five looks to the global south and how Delhi's Paharganj district has been taken to represent a particular idea of India. Here again, 'authenticity' is sold to the global tourist in search of a grimmer and grittier version of the 'real' country.

In chapter six, Terrell Carver considers how language and neoliberal metaphors have been used to reimagine Singapore as a global city. Images of the high tech city (the cyber sexy city) and the creative classes have been drawn upon by Singapore policy makers to reshape a new material reality from an imagined reflection of Silicon Valley. Chapter seven, in a more direct East west contrast, considers Las Vegas and Macau and the production of 'casinopolitanism'. Tim Luke considers how both places have been designed around gaming industry tourism and the idea of an economy-cum-playground. Central again is the neoliberal mobilization of metaphor and mimicry, although this time in the guise of a gambling paradise as represented in Hollywood movies, for Las Vegas, and for Macau in Chinese cinema.

Melbourne is the setting in Chapter eight where Anne McNevin considers the subjectivities of different categories of citizen in regard to immigration. She reveals how asylum seekers are subjugated to a spatial logic of border policing that also represents local manifestations of global market ideologies. These manifestations range from the privatization of immigrant detention to the marketing of the city as a multicultural haven. Meanwhile, in chapter nine, there is a whole different substantive concern and methodology. Here Michael Shapiro examines Yua Nai-Hoi's detective movie Eye in the Sky and how it articulates a regime of surveillance as well as Hong Kong's cultural governance of Chineseness. By way of contrast, Shapiro also reflects on how Berlin (a place where he saw the movie) manages the issue of Germanness. As I mentioned earlier, some of these city comparisons are quite unpredictable! The final chapter by James Spencer focuses on Vietnam and how high speed urban redevelopment is driving South East Asian cities into 
ideologically global facing landscapes. The issue is the lack of concern in long-term spatial effects that may lead to concentrated urban underclasses. There is also attention to new forms of local governance as well as the dangers of the underdevelopment of a more democratic vision of public space.

Here the volume abruptly ends. It is difficult to sum up in a short review the contribution of such a broad range of individual articles. Essentially, each one stands alone, although its place in the text in some way or other triangulates with the set of themes set out by the editors at the beginning. It works perfectly well as a special issue journal volume. However, I am not so convinced that it works as well as an edited book. This would require far more changes to the structure and content. More freedom needs to be given to the editors in this case in order to add or remove papers, reflect on how opinions have changed or matured in the process of making the special issue into a book, or even to provide more considered conclusions at the end.

I like this book, or at least what it is trying to say. The interactions of ideology and urban landscape, in context of neoliberalization and globalization, and how they vary across time and space represent a fundamental contemporary concern. Nonetheless, this book should have provided the opportunity to go farther than the journal special issue. I am reluctant to blame the editors for missing this opportunity. I suspect the publishers concern with the extra income generated by selling the same product twice to university libraries is more the issue.

Open Access This article is distributed under the terms of the Creative Commons Attribution License which permits any use, distribution, and reproduction in any medium, provided the original author(s) and the source are credited. 